\title{
Professional Development and Its Implications for Innovative Teaching and Learning in One South African Higher Education Institution
}

\author{
AK. Isabirye \\ Vaal University of Technology \\ Faculty of Management Sciences, \\ Republic of South Africa \\ E-mail: anthonyi@vut.ac.za \\ KC. Moloi \\ Vaal University of Technology \\ Faculty of Management Sciences, \\ Republic of South Africa \\ E-mail: conniem@vut.ac.za
}

Doi:10.5901/mjss.2013.v4n14p101

Abstract

Teacher learning is an imperative strategic goal for personal growth and development as well as for student learning and academic achievement. Knowledge, on which professionals base their teaching practice, has become less stable and secure and the ways in which it is acquired is diverse. This article outlines a qualitative study that used in-depth, semi-structured interviews to explore professional staff development for innovative teaching and learning at one institution of higher education in South Africa. From the literature review the researchers found that the potential usefulness of focusing on measuring the features of professional development related to the outcomes of teaching and learning. This is deemed more effective than focusing on the structure of the activity employed to develop teachers. From the empirical data they found that, at the institution, focus on professional development is particularly geared to the improvement of teaching and learner assessment. All of the participants interviewed indicated that whilst they had attended assessment workshops very few had attended any of the research workshops or taken advantage of development opportunities available due to, inter alia, heavy teaching workloads and student assessments. Our conclusion is that when teaching and research are not synergised the subject content offered to students often compromises to a greater extent innovation and quality.

Keywords: Professional development, higher education, innovative teaching and learning, Generation Y students, complex technological environment

\section{Introduction}

Teacher learning is an imperative strategic goal for personal growth and development as well as student learning and academic achievement, but according to Harrison (2004) knowledge on which professionals base their teaching practice has become less stable and secure and the ways in which it is acquired diverse. Elder (2004) defines professional development as attainment of skills and knowledge for both personal development and career advancement. In the context of this article, professional development encompasses all types of facilitated learning opportunities situated in practice that enhance innovative teaching and learning. According to Creativity Advantage Incorporated (CAI) (2011), innovation is the process of converting knowledge and ideas into a benefit for commercial or public good. Innovation is, however, not an instantaneous act but a process that occurs over time and consists of a series of actions and decisions (Li \& Lindner, 2007). In the context of this study, the teacher should be able to create value by structuring all the teaching and assessment practices in such a way that they access students' deeper understanding, encourage active participation in the learning process as well as the ability to create contexts for self-directed learning methodologies to enhance deep and independent, reflective learning.

Due to the current nature and the pace of social, economic and technological change, we are advised to become lifelong learners and engage in continuous development in order to contextualise our learning experiences to our spaces of practice (Harrison, 2004; Moloi, 2005; Senge, 2006; Fullan, 2004). Studies that have addressed professional 
development show that in many institutions of higher education, classroom practices lag behind the goal of teaching innovatively, particularly in a technology intensive higher education environment (Organisation for Economic Cooperation and Development (OECD), 2009; Law, Pellgrum \& Plomp, 2010). The National Staff Development Council [NSDC] (2010) regards professional development as a critical issue in teacher quality and student achievement, whilst for Tel, Lundy, Iran, Bielema, Dooley, Anderson and Raulerson (2005) and Swanepoel, Erasmus, Van Wyk, and Schenk (2003), it is any systematic attempt to change professional practices and beliefs of teachers positively and towards an articulated end. What counts as professional development includes a vast range of activities and interactions that may increase teacher knowledge and skills and improve their teaching practice, as well as contribute to their personal, social, and emotional growth as teachers (Desimone, 2009). This knowledge and these skills are also enhanced for the students as active participants, co-constructing new knowledge and understandings. Beheler (2009) notes that, it is in this process that students learn with, not from their teachers, and with each other, rather than simply absorbing information.

Great strides have been taken at the institution under investigation to support staff development and improve the quality of teaching and learning through the department of Teaching, Learning and Academic Development (TLAD). However, the teachers tend predominantly to attend professional development programmes in the form of one-day workshops, seminars and conferences. While these initiatives are useful we argue that they may not sufficiently address individual staff needs to teach innovatively (Collins, 2004). We also argue that one-day interventions may not necessarily facilitate critical thinking that should provide teachers with a rich set of concepts to enable them to think their way through their subjects (Elder, 2004). This compromises the quality of the institution in terms of being the preferred institution of choice, and we argue that exposure to one-day workshops, for example, translates into their employing teaching mechanisms that result in surface learning whereby factual information is extracted from students at the expense of deep learning and the development of higher order skills that lead to deep change in knowledge accumulation and application. The purpose of this paper therefore is to explore how professional development can enhance innovative teaching and learning in the selected institution of higher learning.

\section{Context of the Study}

This investigation focuses on professional staff development at one institution of higher education in South Africa, formerly a Technikon. The institution is now expected to assume the status of a university in all its academic, governance and administrative activities. It has been confronted with numerous challenges that included changing curricula in order to balance the practical component with the theoretical, the development of a new vision and a move towards becoming a university. These challenges also included disciplinary and pedagogic approaches to curriculum delivery, the pressure to publish in accredited journals as well as involvement in meaningful community engagement projects that would translate into research outputs and also generate third stream income. This requires a new way of thinking and doing as well as the entrenchment of scholarship of engagement in all educative acts within the institution.

These new pressures were previously unknown at this institution, where it was generally accepted that academics would be appointed to lecture with minimal qualification of a first degree and some experience in industry. The new demands necessitate the acquisition of higher qualifications from existing staff members, driven by the new vision of the institution becoming a key player and major catalyst for the development of innovation and technological advancement, and people who would contribute meaningfully to the sustainable economy of the region and country through pursuing excellence in teaching, research and community engagement. Through the academic and staff development policy, the institution aims to provide support and assistance to the efforts of individual academics and staff as well as a departmental initiatives to develop and increase the knowledge, skills, competences and abilities of its staff within the disciplinary, cross-disciplinary and pedagogic domains. The institution is committed to continual improvement in the provision of learning opportunities to academics and all other staff members.

\section{Problematising Professional Development}

The institution has had to make a transition from Technikon to university, in terms of curriculum development and delivery, and adopt a teaching-research-innovation nexus philosophy. To achieve this goal it has had to chart its course as a distinct institution of technology and simultaneously acquaint its staff with the features of a university of technology. It has had to craft and implement a teaching philosophy that promotes innovative teaching and learning practices, with pressure to produce and send into industry graduates who can compete with those from other universities, nationally and globally. Although it has gone a long way in implementing innovative teaching and learning practices, empirical research 
by Van Aardt, Goede, Taylor, Kroeze and Pretorius (2010) has revealed that its lecturers still make use of traditional teaching methods and that most students preferred normal lecturing to innovative and self-directed learning in which they became active learners.

Prensky (2004) argues that "the current students at universities, known as Generation Y or the Net students think and process information differently due to the advent of digital technologies that surround them," and therefore, in our schema, those who teach them should not only possess relevant content and pedagogic knowledge but also be able to use more innovative teaching and learning strategies. While the institution in its records aspires to a teaching and learning philosophy informed by constructivism (Martens, Bastiaens \& Kirschner, 2007) it is doubtful whether many of the current teachers understand what it means in their teaching and learning activities. Coetzeee, Botha Kiley, Truman and Tshilongamulenzhe (2012) assert that it is important for organisations to use a systematic approach in the design and delivery of professional development interventions. We are, however, cautioned by Desimore (2009) that we should focus not on the structure of the activity of professional development but rather on measuring features of professional development and how they are related to intended teaching and learning outcomes.

In engaging professional development critical questions emerge: what are the implications of professional development for innovative teaching and learning; and which professional development programmes are suitable to address the needs of teachers to teach innovatively? These are complex questions that require disciplined inquiry if teachers are to improve on poor throughput rates and produce globally employable graduates.

\section{Teacher Professional Development and Its Influence on Innovative Teaching and Student Learning}

A substantial amount of the literature on professional development suggests that student achievement hinges upon improvement in teacher knowledge and skills (OECD, 2009; Darling-Hammond, 1994; Harrison, 2004). Over time, professional development in education has assumed so much importance that it is now recognised as one of the major agents of educational change, improved teacher classroom practice, increased student learning, and achievement (Bissaker, 2001; OECD, 2009; Desimore, 2009). Research by Leu and Ginsburg (2011); Bissaker, (20011); OECD (2009:6) and Desimore (2009) shows that there is a "symbiotic relationship" between professional development and student learning. The authors have argued that if professional staff development has to achieve its intended purpose, development programmes have to be well designed, managed and evaluated.

For Desimore, they should address the three key components of effective professional development which consider: (i) the process of development, (ii) the content required for development, and (iii) the context in which development takes. Professional development plays a crucial role in shaping teacher quality through ensuring that teachers are able to create an environment that best facilitates learning, and have adequate knowledge of content and how to present this material to learners of different ages and aptitudes. Harrison (2004), however, argues that the way professionals learn is controversial, contested and always contingent on social, economic and political conditions.

While the researchers argue for innovative teaching through the use of new information technologies, which include the use of the Internet and problem-based learning, we are realistic in our aspiration, as demonstrated in a study recently undertaken by a consortium of four universities in Australia. The project on "Educating the Net Generation" sought to explore how university students and their teachers were using technologies to support their learning and teaching, and how these might be better harnessed in the future. It found the reality to be more complex than the picture depicted by Prensky's (2004) theorisation of the Generation Y students, and that whilst emerging technologies have the capacity to improve the student learning experience, achieving this requires careful and intentional learning designs and the development of new learning and teaching skills for both students and staff (PVC Learning, Teaching \& Community Engagement, 2011).

\section{Research Design}

To answer the above questions a qualitative, interpretive research approach was chosen to describe and understand (Babbie \& Mouton, 2004) professional development from the narratives of the selected participants. It enabled us to speak to the small sample of participants in their natural setting at the selected institution of higher education. From an epistemological perspective our assumptions are that knowledge is socially created and, as observed by Holliday (2002), qualitative researchers accept that research is ideologically driven. Therefore, the study participants and the researchers co-created the knowledge emerging from the investigation, acknowledging that there is no value-free or bias-free design (Holliday, 2002). Ontologically, we hold basic beliefs about knowledge from a qualitative research stance that there is no 
one single truth. We also believe that how researchers view the world lies behind their theoretical perspectives (Holliday, 2002), and so position ourselves as interpretivists who believe in the inter-subjective meanings that are socially constructed and contextual. Our point of departure is an insider perspective on social action (Babbie \& Mouton, 2004) and so also professional development for innovative teaching and learning.

\subsection{Research methodology}

To better understand our study data was collected through in-depth semi-structured individual interviews with ten staff members, ranging from junior to senior lectures. Following the qualitative data gathering tradition, the interviews were flexible, iterative and continuous (Babbie \& Mouton, 2004). Participants were selected from two of the four faculties, namely Human Sciences and Management Sciences. They were purposefully selected because they had worked there for at least five years. The goal was to understand and describe what we had observed and learnt about professional development from their experiences (Babbie \& Mouton, 2004), which was particularly important because our goal was to make comparisons across individuals. An interview guide with open-ended questions based on issues related to professional development was developed and used to elicit rich information from their experiences. This was useful, considering the small qualitative sample, and all interviews were conducted in a room that allowed privacy, using the same questions. The interviews were tape-recorded with permission and later transcribed and analysed by content to identify recurrent themes (Nieuwenhuis, 2010).

Tesch's (1990) structure of qualitative data analysis was employed to create order of the data (Babbie \& Mouton, 2004), due to its intuitive, epistemological and ontological nature that makes qualitative data analysis a rich but often intricate exercise. The data was synthesised in context (Holliday, 2002) to identify key categories of elements of professional development and the establishment of their connections (Babbie \& Mouton, 2004). The process involved creation of themes based on a number of criteria, including relevance to the research objectives, frequency, universality , differences between research participants, relative importance of the themes within interviews, and emphasis (e.g., emphatic speech). The relationships and differences between the various themes were then examined. This technique was employed so that our research could be adapted to multiple research situations (Bryant \& Charmaz, 2007; Strauss \& Corbin, 1990; Babbie \& Mouton, 2004).

The research was substantively or naturalistically (not statistically) transferable and trustworthy, with credibility ensured through observation by pursuing interpretation of the data in different ways, in conjunction with a process of iterative analysis (Babbie \& Mouton, 2004).

Ethical clearance was obtained from the University and Ethical Committee of the institution under whose auspices the study was conducted. The respondents were assured that the data would be treated in strict confidentiality and that their identity and that of the institution would be protected. All the participants were provided with written information about the study and consent was sought from each. The interview protocol was submitted to the Ethical Committee for clearance. The participants participated voluntarily, and were able to withdraw at any time.

\section{Findings and Discussion}

Ten respondents, code named P1 to P 10, took part in this investigation. Particular characteristics of professional development in the context of the institution became apparent, for example, assessor training programme, improved quality of teaching, ability to teach students from diverse backgrounds, personal initiative for development, attitude change among teachers and students, value added through professional development, and utilised opportunities for personal and professional development. These themes were organised into the conceptual framework.

The participants indicated that they had attended professional development programmes, particularly an assessors training programme which helped them in assessing different types of students and improving the quality of their teaching, particularly of students from different backgrounds. Some indicated that they were now able to identify two types of student attitude to learning, namely negative and positive. The following themes emerged from the data, with examples of responses.

\subsection{Opportunities for professional development in the institution}

The participants indicated that opportunities for professional development positively influenced their teaching activities. Three of the ten also said that they had attended professional development programmes at other universities and that 
these had also positively influenced their teaching activities. In the words of $\mathrm{P} 1$, this epitomised the responses of the majority:

"...I attended the assessor training programme... and became a better teacher. I now know all the different forms of assessment and I'm able to do my job better..."

However, while all indicated that they had attended assessor training programmes, only three mentioned training opportunities related to research programmes, or how these were important for them in facilitating learning. Whatever the type of professional development programme attended, they clearly indicated the positive impact the training had on their teaching. P4's response to a question aimed at determining the impact of the programmes attended captured the general feeling among the participants:

...I attended the writing for publication workshop in 2007, which was facilitated by Prof Kapp and the assessor training programme in $2011 \ldots .$. I am now involved in research a lot. And others (courses) and research helps me a lot.

The focus of professional development in the institution put more emphasis on assessor training, which was somewhat problematic and narrow. One would expect that professional development would be spread to cover diverse needs of different lectures, for example, new technologies for facilitating learning, what it means to be a reflective practitioner, and teaching large classes. This is particularly important for teaching the current students at universities known as Generation Y or the Net students because they think and process information differently, due to the advent of ubiquitous digital technologies. The implication is that more innovative teaching and learning strategies, including Computer Based Teaching (CBT), the Internet and World Wide Web, which incorporate the principles of adult learning, learning-centred teaching approaches, problem-based learning (PBL) and work integrated learning (WIL), should be applied in teaching them.

\subsection{Teacher attitudes towards professional development}

From the participants' responses they seemed positive about professional development training. Not surprisingly the general feeling was that they could teach better after exposure to the professional development programmes. In the words of P6: "After several workshops and activities, I can now teach in such a way that my students are able to apply what they have learnt..." This finding is in line with Desimore's (2009) assertion that professional development includes a wide range of activities and interactions that may increase teacher knowledge and skills and improve their teaching practice. Shear et al. (2009) have also argued that professional development should enable teaching and learning to be structured in such a way that students become active participants in all learning experiences, and are stimulated as opposed to being mere recipients of information. Significantly, they start asking important questions. Echoing P6's views, P8 indicated that professional development:

\footnotetext{
...assisted me to change my attitude. I am able to apply different kinds of assessment. I can teach better so that students are able to apply what they have learnt and, for me as a lecturer, I needed to undergo the assessor training programme.... Whatever I gained in the training workshop was for my personal professional development and my students.
}

\subsection{Motivation for further qualifications}

Apart from improving the participants' way of teaching it emerged that professional development, especially in the area of research, was a major motivation for academics to pursue further qualifications. Four respondents indicated that professional development programmes in research had motivated them to continue with further studies. P8 indicated that:

...my career is progressing in an emphatic way. I am motivated and have been supported by my seniors, HOD, Deans. I want to become a doctor.

In the same vein, P9 indicated that because of the short courses he had been exposed to in research and writing he had been motivated to register for a master's degree in human resource management, and was looking forward to register for a doctorate. Similar sentiments were also expressed by P10, one of the three who attended a professional 
development course related to research and scientific writing:

If I get the necessary support it will help me to complete the revolutionary PhD and publish in peer-reviewed journals. I believe (pause) I will be able to get my PhD because...

Most mentioned that that they were progressing with their careers and pursuing further qualifications.

\subsection{Personal role in professional development}

It emerged from the interviews that if professional development was to achieve the purposes for which it was intended, teachers must be directly involved in the planning the structuring and identification of content of programmes and be fully supported by the senior and line managers. These recommendations are consistent with those of Leu and Ginsburg (2011) and Hunter and Austin's (2004), for whom success of any staff development initiatives requires total commitment and involvement of all stakeholders. From the participants' responses it also emerged that professional development programmes should be continuous and provide follow-up support for further learning. It is also important that these development programmes be continuously evaluated on the basis of their impact on teaching innovatively for students' academic achievement. From the responses, it was evident that success of staff development programmes is also dependent on many other factors, including personal role modelling. Pointing out their qualifications and work experience, several indicated a need for them to be involved in planning and structuring of the professional development programmes. P1 revealed that:

I hold an M+5 degree and I am involved in teaching and learning. I have been working here for seven and a half years.

Similarly, P2 indicated that:

"... I worked at this institution since 2007. I worked as a lecturer since then until 2011. I now work as a training facilitator at EDU. I have a BTech in Human Resource Management, a diploma in Management and Training. I also studied in Mauritius as an exchange student programme for one year."

\subsection{Value added to innovative teaching and learning}

Several respondents had added value to innovative teaching and learning, providing responses in line with the research findings of the QECD (2009), which show that innovative teachers have the ability and skills to create a positive learning environment that supports student learning, as an environment in which the organisation of learning space reflects creativity on the part of the teacher and enables the students to be productive, active agents in individual and cooperative learning encounters. Thus, professional development should not only be designed according to the teachers' needs, but also guided by coherent and long-term plans. Since innovative methods of teaching and learning entail collaboration and problem solving, professional development programmes should be designed around collaborative and problem-solving. These excerpts captured some of the participants' views:

P1: I attended the assessor training programme, which has helped me to assess different types of students. The programme helped to improve the quality of my teaching and I can teach students from different backgrounds. I am able to identify two types of student attitudes, namely negative and positive attitudes towards learning.

P2: Nothing that I did not like. It assisted me to structure questions, to assess students. Before, I used one way of assessing students. After the assessor training I could now use more ways of assessing students.

\section{Conclusion}

This paper explored a number of issues pertaining to professional development and its implication for innovative teaching and learning in higher education. The concept was discussed and suggestions made for how this can enhance innovative teaching and learning. We argue that if teachers are to be equipped to teach innovatively there is a need for wellstructured and continuous staff development programmes that are specifically geared to the context and individual needs of teachers and their students. We also argue that planning and structuring of the programme per se may not yield the expected professional development results, as there are several other factors that could influence its success and 
effectiveness.

We therefore recommend that in addition to planning and instituting long-term development programmes, the institution under investigation should ensure that the programmes are inclusive, responding to the diverse needs of teachers and those of their students and their contexts, and that focus should not only be on the assessor training, as indicated by many of the participants. The conclusion that we draw is supported by the findings of Aardt et al.'s (2010) study, which shows that many students still experience instruction that is largely lecture-based in today's classrooms, despite the proliferation of information and technology communications. Against this reality, and the significant number of university staff who may not have professional qualifications in teaching, this paper argues for a systematic form of staff development that enables teachers to keep up with evolving student needs and enhance innovative teaching.

\section{References}

Babbie, E. \& Mouton, J. 2004. The practice of social research. South African edition. Oxford: University Press.

Beheler, B. 2009. Student Centred Learning Environments and Technology. EdTech, Boise State University.

Bissaker, K. 2001. Did they get what they came for? Evaluating lecturers' learning. International Education Journal, 294) (Online) Available: http://ehlt.flinders.edu.au/education/iej/articles/v2n4/BISSAKER/PAPER.PDF. Accessed: (July 13,2012)

Bryant, T. \& Charmaz, K. 2007. The SAGE Handbook of Grounded Theory. Paperback Edition. London: Sage.

Coetzee, M., Kiley, J. \& Truman, K. 2009. Practising Education, Training and Development in South African Organisations. Cape Town: Juta.

Collins, J. 2004. Education Techniques for Lifelong Learning. Radio Graphics, 24(5). (Online) Available at: http://uphs.upenn.ed/radiology/education/documents/Adult-learning-principles.pdf (June 26, 2012)

Creative Advantage Inc. 2011. What is innovation? (Online) Available: www.creativeadvantage.com/innovatio-definition. (September 26, 2012)

Darling-Hammond, L. (ed.). 1994. Professional development schools. Schools for developing a profession. New York: Teachers College.

Desimone, L. 2009. "Improving impact studies of teachers' professional development: Towards better conceptualization and measures," Educational Researcher, 38, 181-199.

Elder, L. 2004. Professional development model for colleges and universities that foster critical thinking. The Critical Thinking Community. (Online) Available: Criticalthinking.org. Foundation for Critical Thinking (September 26, 2012)

Fullan, M. 2004. Looking in a culture of change. Personal guide and workbook. San Francisco: Jossey Bass.

Harrison, J. 2004. Professional learning and the reflective practitioner. London: Sage.

Holliday, A. 2002. Doing and writing qualitative research. London: Sage.

Hunter, C. \& Austin, L. 2004. Supporting lecturers in their move towards a new a learning environment. (Online) Available: http://www.col.org/pcf3/papers/PDFs/Hunter_Austin.pdf. Accessed: (July 13,2012)

Law, N., Pellgrum, W., \& Plomp, T. 2010. Pedagogy and ICT use in schools around the world: Findings from IEA SITES 2006 study. Hong Kong: Comparative Education Research Centre.

Leu, E \& Ginsburg, M. 2011. First Principles: Designing effective Education Program for In-service Lecturer Professional Development. Washington, DC: USAID.

Li, Y. \& Li, L. 2003. Construct Learning Support System For Distance Education in China. Paper presented at $10^{\text {th }}$ Cambridge International Conference on Open and Distance Learning.

Martens, R; Bastiaens, T \& Kirschner, P.A (2007). New Learning Design in Distance Education: The impact on student perception and motivation. Distance Education, 28 (1), 81-93.

Moloi KC 2005. The school as a learning organization: Reconceptualising school practices in South Africa. Pretoria: Van Schaik.

National Staff Development Council [NSDC]. 2010. Definition of professional development. (Online) Available: http://www.nsdc.org/standfor/definition.cfm. Accessed: (August 25, 2010)

Nieuwenhuis, J. 2010. Analysing qualitative data. In: Maree, K. (ed.). First steps in research (pp. 19-29). Pretoria: Van Schaik.

Organisation for Economic Co-operation and Development (OECD). 2009. Creating effective teaching and learning environments. First results from TALIS. Paris, OECD.

Prensky, M. 2004. Capturing the value of "Generation Tech" employees. (Electronic version). Strategy + BusinessPVC Learning, Teaching \& Community Engagement. 2011. Charles Darwin University. OLTCE.

Senge, P. 2006. The Fifth Discipline: The Art \& Practice of The Learning Organisation. New York: Doubleday.

Shear, L., Means, B., Gorges, T., Toyama, Y., Gallagher, L., Estrella, G. \& Lundh, P. 2009. The Microsoft Innovative Schools program Year 1 evaluation report. Seattle, Microsoft.

Strauss, J.S. \& Corbin, J. 1990. Basics of qualitative research. Newbury Park, CA: Sage.

Swanepoel, B., Erasmus, B., Van Wyk, M. \& Schenk, H. 2003. "Training and Developing Employees: Organisational Perspective." In Swanepoel, B. (ed.). Human Resource Management. Theory and Practice. Cape Town: Juta.

Tesch, R. 1990. Qualitative research: Analysis types and software tools. New York: The Falmer Press.

Telg, R.W; Lundy, L., Iran, T., Bielema, C., Dooley, K., Anderson, E. \& Raulerson, R. 2005. Distance Education Training for Distance Education Trainers. The roadmap to effective distance education instructional design Project. The Quarterly Review of Distance Education, 6, 331-342. 
Van Aardt, C, Goede, R, Taylor, E, Kroeze, J.H \& Pretorius, P.D. 2010. Engineering students at the Vaal University of Technology: Analysing learning style preferences. (Online) Available: http://dspace.nwu.ac.za/handle/10394/3829?show=full. ( September 26, 2012) 